\title{
ANALISIS UNSUR INTRINSIK DALAM NOVEL KENANGA KARYA OKA RUSMINI DAN IMPLIKASINYA UNTUK PENGAJARAN SASTRA
}

\author{
Suprapti \\ Sekolah Tinggi Elektronika dan Komputer Semarang \\ suprapti@stekom.ac.id
}

\begin{abstract}
Abstrak
Novel Kenanga ditulis oleh Oka Rusmini, diterbitkan oleh Grasindo pada tahun 2004. Novel ini pada mulanya dimuat di Koran Tempo tanggal 20 Agustus 2002 sampai dengan 17 Desember 2002 sebagai cerita bersambung dan merupakan novel ketiga Oka Rusmini setelah novel terdahulunya Tarian Bumi dan Sagra yang juga merupakan cerita bersambung. Perkembangan novel di Indonesia cukup pesat, terbukti dengan banyaknya novel yang telah diterbitkan. Novel-novel tersebut mempunyai bermacam-macam tema dan isi, antara lain tentang problema sosial yang terjadi dalam masyarakat pada umumnya. Masalah yang diteliti yaitu unsur intrinsik apa saja yang langsung berhubungan dengan tokoh dalam novel Kenanga Karya Oka Rusmini. Sedangkan tujuan penelitian ini mengidentifikasi unsur intrinsik yang terdapat dalam novel Kenanga Karya Oka Rusmini, yakni tokoh, penokohan, dan latar. Jenis penelitian ini kualitatif dengan menggunakan sumber data dari novel Kenanga. Teknik pengumpulan data kepustakaan. Teknik analisis data dengan metode deskriptif. Hasil penelitian ini dapat digunakan sebagai sumbangan dalam pengembangan di dunia pendidikan, terutama di bidang sastra.
\end{abstract}

Kata Kunci: Unsur Intrinsik; Novel; Implikasi; Pengajaran.

\begin{abstract}
The novel Kenanga was written by Oka Rusmini, published by Grasindo in 2004. The novel was originally published in Koran Tempo on August 20, 2002 to December 17, 2002 as a continuing story and is Oka Rusmini's third novel after the previous novel Tarian Bumi and Sagra which is also a seria story. The development of novels in Indonesia is quite rapid, as evidenced by the number of novels that have been published. These novels have a variety of themes and content, including about social problems that occur in society in general. The problem under study is what intrinsic elements are directly related to the characters in the novel Kenanga Karya Oka Rusmini. While the objective of this study is to identify the intrinsic elements contained in the novel Kenanga Karya Oka Rusmini, namely characters, characterizations, and settings. This type of research is qualitative using data sources from the novel Kenanga. The data were collected through library research and descriptive method was used in analysis the data. The results of this study can be used as a contribution in the development of education, especially in the field of literature.
\end{abstract}

Keywords: Intrinsic Element; Novel; Implications; Teaching. 
Edutainment : Jurnal Ilmu Pendidikan dan Kependidikan

Volume 7 Nomor 2 Edisi Juli-Desember 2019

\section{PENDAHULUAN}

Novel sebagai salah satu bentuk karya sastra dapat merefleksikan kenyataan di sekitar kehidupan manusia dengan ruang lingkup yang luas. Hal itu disebabkan oleh adanya novel yang mempunyai kecenderungan untuk memunculkan adanya "Kompleksitas" (Sayuti, 2000:10). Adanya kompleksitas tersebut menyebabkan novel dapat mengungkapkan seluruh episode perjalanan tokoh ceritanya.

Novel menggambarkan perjalanan hidup manusia. Sebagai salah satu karya seni, di dalam novel terdapat pelajaran bagi pembaca.

Sebuah novel dapat dijadikan bahan untuk mempelajari kehidupan manusia yang sesungguhnya. Berbagai sifat manusia dan gambaran hidup terekam semua dalam sebuah novel. Gambaran hidup yang terekam dalam sebuah novel acap terwujud dalam bentuk konflik. Konflik tersebut berupa konflik antartokoh yang dipaparkan pengarang melalui gayanya sendiri. Secara umum dapat dijabarkan bahwa masalah itu timbul apabila ada perbedaan atau konflik antara keadaan atau konflik antara keadaan satu dengan yang lain dalam rangka mencapai suatu tujuan.

Masalah yang akan diungkap dalam pembahasan ini, yakni unsur instrinsik apa saja yang ada dalam novel kenanga karya
Oka Rusmini. Sedangkan tujuannya mengidentifikasi unsur intrinsik yang terdapat dalam novel Kenanga karya Oka Rusmini. Penelitian ini diharapkan dapat bermanfaat secara teoretis dan praktis. Adapun manfaat dalam penelitian ini secara teoretis dapat dijadikan pijakan awal dalam memahami novel Kenanga. Pembahasan unsur intrinsik dalam novel Kenanga yaitu satu upaya mengungkap dan menambah khasanah bagi studi linguistik.

Secara praktis, bagi para guru hasil penelitian ini dapat dimanfaatkan sebagai salah satu arternatif bahan ajar dalam pengajaran sastra. Hal ini mengingat bahwa bahan ajar yang ada di sekolah kurang mamadai. Oleh karena itu, kajian novel Kenanga tentunya dapat dijadikan sebagai materi tambahan.

Hasil penelitian ini juga dapat bermanfaat bagi guru sebagai referensi pengajaran unsur intrinsik dalam novel.

\section{METODE PENELITIAN}

Metode yang digunakan dalam penelitian ini dengan menggunakan metode deskriptif kualitatif, sehingga dapat menghasilkan data yang diperlukan dalam bentuk kutipan kata-kata. Teknik pengumpulan data dalam penelitian ini menggunakan teknik membaca dan teknik mencatat. Teknik yang digunakan untuk menganalisis data yaitu teknik analisis deskriptif (Aminuddin, 1994:44). 
Edutainment : Jurnal Ilmu Pendidikan dan Kependidikan

Volume 7 Nomor 2 Edisi Juli-Desember 2019

Cara kerja teknik deskriptif yaitu membaca keseluruhan teks novel Kenanga karya Oka Rusmini secara heuristik dan hermeneutik. Pembacaan hermeneutik berarti pembacaan karya sasra secara berulang-ulang dari awal sampai akhir dengan penafsiran atau pemberian makna berdasarkan konvensi sastra. Sedangkan pembacaan heuristik yaitu pembacaan karya sastra berdasarkan konvensi bahasa atau sistem bahasa sesuai dengan kedudukan bahasa sebagai sistem tanda (semiotik) tingkat pertama. Dalam pembacaan ini, semua yang tidak bisa dibuat biasa atau dinaturalisasikan sesuai dengan sistem bahasa Normatif (Pradopo, 1997:195-297).

\section{HASIL DAN PEMBAHASAN}

Tokoh-tokoh yang terdapat dalam novel ini, yakni Kenanga, Intan, Kencana, Rahyuda, Bhuana, Meme Made, Ratu Ibu, Ratu Aji, dan Jero Kemuning.

Berikut kutipan yang menunjukkan tokoh yang paling sering diceritakan.

"Bagi Bhuana, Kenanga adalah bagian dari napasnya. Perempuan yang tidak bisa digantikan oleh siapapun juga. Menatap matanya, Bhuana seperti menemukan serpihan luka masa lalu yang amat kelam. Mata itu seperti lubang persembunyian waktu yang selalu membuatnya tergetar dalam takjub oleh pesona rahasianya. Bahkan sudah sejak pertama kali mereka bertemu dulu, Bhuana langsung sadar bahwa inilah perempuan yang dicarinya. Ibu bagi calon anak-anaknya kelak! Tapi apakah itu mungkin? Tahukah perempuan itu betapa dirinya setengah mati mencintainya?" (Rusmini, 2003:48).

Kutipan di atas menunjukkan bahwa tokoh Kenanga merupakan tokoh yang diceritakan oleh Bhuana. Dalam hal ini Bhuana mencintainya pada pertemuan pertama, karena Bhuana merasa Kenanga adalah sosok perempuan yang dicarinya.

Berikut ini kutipan yang menunjukkan Kenanga juga diceritakan oleh Profesor Rahyuda.

"Dasar anak muda, demikian simpul Rahyuda sekenanya. Namun seandainya pun ia tahu duduk perkaranya, dapat dipastikan keheranannya akan semakin besar saja. Keputusan Kenanga untuk pindak ke Yogyakarta sungguh tidak masuk akal. Kota tua itu adalah sosok saksi bisu bagi aib yang dialaminya. Bukannya lari menjauh, Kenanga justru nekad memasuki liang luka dan trauma yang telah mengubah jalan hidupnya untuk selamanya. Bila dibayangkan tekanan batin yang harus ditanggungnya tatkala jejak-jejak pengalaman kelam itu seakan kekal mengepung setiap jengkal ruang” (Rusmini, 3003:53).

Dari kutipan di atas menunjukkan bahwa Kenanga diceritakan oleh Profesor Rahyuda yang tidak habis pikir tiba-tiba Kenanga langsung menerima tawaran 


\section{Edutainment : Jurnal Ilmu Pendidikan dan Kependidikan}

Volume 7 Nomor 2 Edisi Juli-Desember 2019

tugas belajar di Yogyakarta, padahal kota tersebut sangat asing bagi Kenanga.

Tokoh Kenanga juga diceritakan oleh Biang Logaya, berikut kutipan:

"Sial sekali nasib Kenanga. Dia tidak bisa menerima perkawinan Kencana. Sudah dilangkahi, eh suami kencana orangnya ganteng dan gagah sekali. Dokter, lagi. Jelas saja hatinya sakit. Cemburu dia. Tiang tahu perasaannya, tiang juga perempuan. Apalagi Kenanga kan aslinya naksir berat sama suami Kencana. Cuma tidak ditanggapi. Istilahnya, betepuk sebelah tangan. Makanya dia dendam betul.sampai tidak mau datang ke upacara perkawinan adiknya sendiri. Salahnya sendiri juga, habis Kenanga aneh begitu. Semua orang tahu dia ada main dengan Rahyuda. Itu, perjaka karatan dari Griya Kesiman. Ya mana mau dokter ganteng itu dengan dia, biarpun seribu kali lebih pintar dibanding adiknya. Lalu minggatlah dia ke Yogya. Katanya sekolah. Sekolah apa? Aslinya dia patah hati. Namanya juga perasaan perempuan. Tiang paham betul itu. Istilahnya, frustasi, begitu. Kasihan sekali” (Rusmini, 2003:62-63).

Kutipan di atas menunjukkan bahwa Kenanga digosipkan oleh Biang Logaya bahwa Kenanga cemburu dengan Kencana, karena Kencana seorang perempuan yang sempurna dibandingkan dengan Kenanga, dan Kencana bisa mendapatkan semuanya sementara Kenanga termasuk orangnya aneh.

Kenanga juga diceritakan oleh Ratu Aji dan Ratu Ibu dalam kutipan berikut:

"AJI, apa yang sesungguhnya terjadi pada Kenanga? Entahlah, Yu. Semakin besar umurnya semakin sulit tiang mengerti. Mungkin ini salah kita.... Salah kita? Perhatian kita terlalu berlebihan pada Kencana. Kita lupa bahwa Kenanga juga butuh kasih sayang. Apakah itu yang membuatnya jadi begitu keras kepala? Mungkin saja. Ah, Yu, kenapa baru sekarang kita menyadarinya? Setelah Kenanga terlanjur dewasa... Tapi perhatiannya kepada wong jero kkecil itu, Aji... bagaimana, ya... rasanya terlalu berlebihan. Seperti ibu pada anaknya. Ya. Tiang juga merasakan itu. Kadang tiang sampai takut melihat caranya mendekap Intan. Apalagi tiang. Masalahnya kenapa seperti tidak ada minat berumah tangga" (Rusmini, 2003:97).

Kutipan di atas menunjukkan bahwa Kenanga dibicarakan Ratu Aji dan Ratu Ibu, karena Kenanga belakangan ini tingkahnya aneh tidak seperti biasanya. Kenanga menjadi sosok yang sangat menyayangi anak kecil yang statusnya hanya sebagai Wong Jero.

Hal tersebut juga terlihat pada kutipan berikut.

"Itu tiang juga tahu. Dia membenci semua laki-laki yang ingin dekat 


\section{Edutainment : Jurnal Ilmu Pendidikan dan Kependidikan}

Volume 7 Nomor 2 Edisi Juli-Desember 2019

dengannya. Lihat saja perlakuannya pada

Bhuana. Kasar. Padahal seharusnya

Kenanga berterima kasih pada mantu kita itu. Mana ada ipar yang begitu baik seperti dia. Begitu penuh perhatian. Aji lihat sendiri waktu Kenanga sakit, Bhuana begitu hormat padanya. Tapi anak kita itu malah uring-uringan terus. Tidak tahu apa maunya jujur saja, Aji, Tiang malu pada Bhuana. Tiang sempat minta maaf. Untung dia tidak tersinggung. Tidak marah. Dasar memang orangnya baik. Mungkin dia sudah hapal dengan sifat Kenanga yang suka aneh. Setelah tiang pikir-pikir, Aji, bisa saja dia jadi begitu karena iri sama Kencana. Mungkin Kenanga ingin membalas dendam, Aji” (Rusmini, 2003:97-98).

Kutipan di atas menunjukkan bahwa Kenanga diceritakan Ratu Aji dan Ratu Ibu, karena sikap Kenanga terhadap Bhuana yang terlihat hanya kebencian semata.

Hal tersebut dijelaskan pada kutipan berikut.

"Aji tahu, kemarin Kenanga bicara serius pada tiang di meja makan. Bicara apa? Dia minta dibuatkan otonan untuk luh Intan! Apa itu tidak gila, namanya? Dia pikir Intan itu siapa? Anak siapa? Kita ini bangsawan. Bisa jatuh harga diri kita di depan orang-orang. Coba Aji pikir, apa kata orang Griya ini kalau kita turuti kemuan ngawurnya itu? Kalau kita mengalah, seperti Aji bilang tadi? Semua pasti berpikir kita sudah miring!" (Rusmini, 2003:99).

Kutipan di atas menunjukkan sikap dan tindakan Kenanga aneh, Kenanga meminta kepada ibunya dibuatkan otonan untuk luh Intan. Hal tersebut dirasa ibu tidak mungkin, karena Intan hanya anak yang tidak jelas asal-usulnya dan statusnya di Griya hanya sebagai Wong Jero.

Jadi, berdasarkan analisis di atas dapat diketahui bahwa Kenanga merupakan tokoh yang sering diceritakan oleh semua tokoh pembangun cerita.

Tokoh Kenanga juga tokoh yang paling banyak terlibat dengan tokoh-tokoh lain. Misalnya dengan Intan, Kencana, Rahyuda, Bhuana, Meme Made, Ratu Aji, Ratu Ibu, Jero Kemuning, Mahendra.

Kenanga berhubungan dengan Intan. Hubungan dengan Intan terlihat pada kutipan berikut.

"Bocah itu begerak mendekat. Kenanga hanya diam. Pasti tentang sekolah tiang. Sekarang tiang sudah bisa baca. Sungguh! Tiang tidak mau masuk TK lagi! Langsung kelas satu saja. Masuk Tk biayanya banyak. Tiang tidak mau merepotkan Ratu, kata Intan datar, tanpa emosi, ditengah kantuknya yang tampak masih berkecamuk. Kenanga memeluk Intan erat-erat. Dan Intan pun balas memeluk, lalu kembali menetapnya. Bocah itu seolah dapat merasakan sesuatu yang 


\section{Edutainment : Jurnal Ilmu Pendidikan dan Kependidikan}

Volume 7 Nomor 2 Edisi Juli-Desember 2019

aneh mengalir deras dalam diri Kenanga setiap kali bersentuhan dengannya. Tetapi siapa yang dapat mengaburkan mata dan kejujuran seorang bocah enam tahun?" (Rusmini, 2003:3).

Kutipan di atas menunjukkan bahwa Kenanga berhubungan dengan Intan seorang bocah yang berumur enam tahun ingin masuk Sekolah Dasar karena Intan sudah bisa baca jadi Intan tidak ingin disekolahkan di TK lagi.

Kenanga juga berhubungan dengan Kencana, berikut kutipannya.

"Lalu cari siapa? Kenanga tahu persis, kalu Kencana pulang ke rumah, pasti ada maunya. Kenanga menarik napas. Senyum Kencana mengembang gamang. Penuh rahasia. Kenanga tahu adiknya menyembunyikan sesuatu. Tapi hanya sepersekian detik, dan wajah Kencana telah berubah cerah. Tiang perlu sama Mbok, bisik Kencana, sedikit merajuk" (Rusmini, 2003:14).

Kutipan di atas menunjukkan bahwa Kenanga berhubungan dengan kencana pada saat Kencana pulang ke rumah mencari Kenanga, karena ada hal penting yang ingin dibicarakan dengan kenanga.

Kenanga juga berhubungan dengan Rahyuda. Berikut kutipannya.

"Betapa terharunya Kenanga ketika Rahyuda dengan hati-hati sekali mengeluarkan setumpuk kartu pos yang telah berubah warna. Hyang Jagat, sutradara segala kekuatan alam, cinta apakah yang Kau tanam di tubuh laki-laki ini? Cintanya begitu penuh misteri, berselimut rahasia, tapi romantik dan kharismatik. Kenanga dapat merasakan sebentuk kedalaman yang luar biasa. Kedalaman yang membuat perasaan perempuannya kesakitan! Lihat, Kenanga, kartu-kartu ini sangat indah, kata Rahyuda setengah bergumam, seraya menyentuh tumpukan kartu-kartu itu dengan penuh perasaan. Kenanga menaruh bukunya di rak, lalu berjalan mendekati Rahyuda. Mata tua milik gurunya telah basah" (Rusmini, 2003:32-33).

Kutipan di atas menunjukkan bahwa Kenanga berhubungan dengan Rahyuda ketika Rahyuda menceritakan kisah cintanya dengan Jero Kuning yang penuh misteri, berselimut rahasia, tetapi romantik dan kharismatik.

Sementara itu, tokoh bawahan merupakan tokoh yang tidak sentral kedudukannya di dalam cerita, tetapi kehadirannya sangat diperlukan untuk menunjang dan mendukung tokoh utama.

Intan merupakan tokoh bawahan. Hal tersebut terlihat pada kutipan berikut.

"Intan tidak habis pikir kenapa perempuan itu senang sekali memancingmancing perkara dengannya, seolah-oleh menikmatinya. Bahkan untuk sekedar ngaturang canag, menghaturkan sesaji berupa bunga ke pura yang jaraknya hanya 


\section{Edutainment : Jurnal Ilmu Pendidikan dan Kependidikan}

Volume 7 Nomor 2 Edisi Juli-Desember 2019

dua puluh meter, misalnya, Galuh selalu memanggil Intan untuk membawakan bokor berisi sesaji, lalu berjalan melenggang santai sambil tersenyumsenyum tengik. Intan tahu, dirinya mesti tahu diri. Sebagai wang jero, dia sadar bahwa tugasnya memang untuk disuruhsuruh. Namun ia tetap tidak bisa paham kenapa dirinya asing” (Rusmini, 2003:139).

Kutipan di atas menunjukkan bahwa tokoh Intan merupakan tokoh bawahan yang kehadirannya mengisi rangkaian peristiwa yang ada dalam cerita.

Kencana merupakan tokoh bawahan. Berikut kutipannya.

"Sejenak menarik napas, Rahyuda melanjutkan, serjak saat itu tiang emnyadari bahwa perkawinan itu barang mahal. Tidak cukup hanya modal cinta saja, tapi harus ada rasio. Jero Kemuning, yang sedari tadi ikut mendengarkan, langsung membalikkan badan. Sekilas terpantul benih air di matanya. Dia berjalan pelan meninggalkan ruang kerja Profesor Rahyuda. Hyang Jagat! Pekik Kenanga dalam hati, cinta model apakah yang telah ditanamkan hidup di rumah ini?" (Rusmini, 2003:28).

Kutipan di atas menunjukkan bahwa Profesor Rahyuda kehadirannya diperlukan dalam cerita sebagai teman dan sahabat bagi Kenanga dalam dunia pendidikan.
Tokoh Kenanga dilukiskan seperti kutipan berikut.

"Rasa dendam, senang, kecewa, takut, sedih, bahagia, bertarung seru dalam lubuk batin Kenanga. Pengakuan Bhuana terlalu dahsyat. Sama sekali di luar jangkauan perkiraannya. Selama ini ia merasa harus mengasah pisau dendam dihatinya hingga berkilap tanpa karat. Demi sepotong masa silam yang terbunuh oleh tangan kotor laki-laki itu. Tapi tiba-tiba saja ia datang dengan kabar bahwa buah masa silam itu masih hidup, bahkan tumbuh di tempat yang sedemikian dekat. Sebuah kabar yang terlampau muskil untuk dapat dipercaya sebagai kebenaran, tapi sekaligus mustahil untuk dibuang begitu saja ke keranjang omong kosong" (Rusmini, 2003:91).

Kutipan di atas menunjukkan bahwa Kenanga dilukiskan sebagai sosok perempuan yang tegar dalam menghadapi masalah. Hal itu diungkapkan oleh pengarang secara langsung.

Sifat lain Kenanga terlihat pada kutipan berikut.

"Andai kau tahu, Intan, betapa kau adalah segala-galanya bagiku. Kaulah sumber yang menghidupi kehidupanku. Mata air yang tiada putus menyiram gersang keperempuanku. Andai kau tahu... malam menuntun kerentaannya. Musik gesek dedaun kelapa dipinggirpinggir Kuri Gede mengalun lamat, mengelus buluh-buluh hati yang merintih. 


\section{Edutainment : Jurnal Ilmu Pendidikan dan Kependidikan}

Volume 7 Nomor 2 Edisi Juli-Desember 2019

Sesekali burung-burung bersiul murung.

Lalu angin yang membisikkan sesuatu.

Lalu kaok burung gagak. Kenanga tercekat. Siapakah yang segera akan pergi?" (Rusmini, 2003:222).

Kutipan di atas menunjukkan bahwa Kenanga dilukiskan sebagai seorang ibu yang sangat menyayangi anaknya dan menganggap Intan bagian dari kehidupannya. Hal tersebut diungkapkan oleh pengarang secara tidak langsung.

Jadi Kenanga mempunyai sifat tegar dalam menghadapi masalah, sosok ibu yang sangat menyayangi anaknya.

Sementara itu, tokoh Intan dilukiskan seperti kutipan berikut.

"Hyang Jagat, desah Intan dalam hati, telah kau berikan tiang perempuan terbaik dalam hidup tiang. Tolong tunjukkan jalan pada tiang untuk bisa membuatnya tersenyum. Dia terlalu baik bagi tiang. Dan tiang merasa dia adalah milik tiang, bagian dari roh tiang, sekalipun tiang tahu itu terlalu mustahil. Bagaimana mungkin seorang sudra seperti tiang memiliki ibu berparas agung seperti Ratu Kenanga? Seorang perempuan brahmana" (Rusmini, 2003:135).

Kutipan di atas menunjukkan bahwa Intan sangat menyayangi Kenanga. Hal tersebut diungkapkan pengarang secara tidak langsung.

Sifat lain Intan terlihat pada kutipan berikut.
"Bukankah selama ini tiang selalu mengalah, bahkan ketika kau perlakukan tiang dengan sangat tidak hormat! Tiang berpikir semakin dewasa kita semakin mengerti arti kehidupan ini. Seperti tiang yang berusaha tahu dari menumpang di Griya orang. Di rumah yang bukan siapasiapa tiang" (Rusmini, 2003:268).

Kutipan di atas menunjukkan bahwa Intan selalu mengalah dan menghormati orang-orang yang ada di Griya. Hal tersebut diungkapkan pengarang secara langsung.

Jadi Intan merupakan anak yang menyayangi Kenanga dan selalu mengalah serta menghormati orang-orang yang ada di Griya. Dia hanya Wang Jero yang beruntung diterima di keluarga Brahmana. dalam keseharian dia selalu mengalah dan hormat kepada siapapun yang ada di Griya.

Adapun latar tempat pada novel ini terlihat pada kutipan berikut.

"Adat dilingkungan Griya lazimnya memang demikian. Anak-anak orang biasa yang tadinya bekerja namun miskin dan tak mampu sekolah, sering diserahkan orang tuanya untuk jadi pembantu di Griya. Sekaligus sebagai tanda persembahan dan bukti kesetiaan pada kaum bangsawan. Ada kepercayaan bahwa dengan mengabdi pada Griya, mereka akan senantiasa dilimpahi kebahagiaan" (Rusmini, 2003:6). 
Edutainment : Jurnal Ilmu Pendidikan dan Kependidikan

Volume 7 Nomor 2 Edisi Juli-Desember 2019

Kutipan di atas menunjukkan bahwa latar tampat terjadinya peristiwa di Griya (merupakan rumah tempat tinggal para kasta brahmana yang ada di Bali).

Tempat terjadinya peristiwa juga terdapat pada kutipan berikut. "Ketika sedang khusuk bersembahyang di merajan, pura keluarga, seorang perempuan tua bertubuh kurus muncul dari balik pelinggih, tugu batu yang disucikan" (Rusmini, 2003:107).

Kutipan tersebut menunjukkan bahwa latar terjadinya peristiwa di merajan yang merupakan pura keluarga. Hal tersebut mencerminkan bahwa pura merupakan tempat semabahyang yang ada di Bali.

Bali merupakan tempat terjadinya peristiwa. Terlihat pada kutipan berikut. "USAI seminggu layon disemayamkan di Bale, mayat Jero kemuning memasuki api pembakaran. Upacara ngaben itu berlangsung besar-besaran" (Rusmini, 2003:129). Kutipan tersebut menunjukkan bahwa ritual pembakaran mayat (ngaben) hanya ada di Bali. Hal tersebut terjadi pada mayat Kemuning dimasukkan api pembakaran.

Sementara itu, mengenai waktu terjadinya peristiwa terlihat pada kutipan berikut.

"Lampu-lampu dipadamkan. Namun sampai jauh malam itu Kenanga tahu bahwa Bhuana masih bertahan di depan pintu. Dalam gelap yang mengungkung ruang kamar, berbagai bayang-bayang asing silih berganti menyinggahi benak Kenanga, lalu lebur jadi sebentuk sosok tunggal Bhuana. Laki-laki teraneh yang pernah dikenalnya” (Rusmini, 2003:56).

Kutipan di atas menunjukkan bahwa waktu terjadinya peristiwa pada saat malam hari yang gelap tanpa nyala lampulampu.

Hal tersebut juga terlihat pada kutipan berikut.

"Paginya Kenanga tergeragap bangun oleh suara ketukan keras pada pintu. Ternyata yang datang ibu pemilik rumah, perempuan setengah tua yang tidak punya siapa-siapa lagi di dunia ini. Meskipun tinggal bersebelahan, selama hampir tiga bulan menempati kontrakannya, Kenanga belum sempat berbicara banyak dengan sang pemilik rumah. Dan pagi ini ia mendadak datang berkunjung begitu saja. Dengan sopan perempuan itu duduk di ruang tamu. Tatapannya begitu hangat oleh cahaya persaudaraan” (Rusmini, 2003:57).

Kutipan di atas menunjukkan bahwa peristiwa terjadi pada saat pagi hari di rumah ibu kontrakan Kenaga di Yogyakarta.

Sementara latar sosial novel ini merupakan kehidupan kalangan atas, hal ini terlihat pada kutipan berikut.

"Kaum brahmana adalah surya. Matahari. Tampat tiang adalah sebagai pelayan mereka. Bukan mereka yang harus 
Edutainment : Jurnal Ilmu Pendidikan dan Kependidikan

Volume 7 Nomor 2 Edisi Juli-Desember 2019

menghargai tiang, sebagaimana yang kau maui. Itu terbalik, Ratu. Memang, tiang tahu, gaya mereka kadang-kadang terlalu sok. Tapi bukankah itu sudah menjadi pakem dalam masyarakat kita? Kenapa Ratu harus mempersoalkannya, hanya demi seorang perempuan sudra seperti tiang!" (Rusmini, 2003:136).

Kutipan di atas menunjukkan bahwa latar sosial masyarakat pada kelas atas, yakni kaum brahmana.

Hal tersebut diperjelas dengan kutipan di bawah ini.

"Begitu seorang perempuan mendapat status sebagai istri, apa lagi istri brahmana, secara sosial maupun kosmis dia adalah seorang perempuan baru milik keluarga sang suami. Pernah Kenanga tidak habis pikir, kenapa Rahyuda begitu sering menyanjung-nyanjung Kemuning" (Rusmini, 2003:25).

Kutipan di atas menunjukkan bahwa latar sosial masyarakat dalam cerita tersebut adalah kaum brahmana yaitu merupakan kaum bangsawan.

Hal tersebut juga terlihat pada kutipan berikut.

"Sedan Mazda biru-metalik berhenti di depan toko buku. Kenanga keluar dari mobil bersama seorang laki-laki yang lebih pantas jadi adiknya. Mereka tampak begitu mesra. Sejenak menghilang ke dalam toko, mereka kemudian muncul dengan menenteng satu tas plastik penuh buku anak-anak" (Rusmini, 2003:115).

Kutipan di atas menunjukkan bahwa sedan Mazda biru-metalik hanya dimiliki para kaum bangsawan atau brahmana.

Kaum sudra juga menjadi latar dalam novel ini berikut kutipannya.

"Keluarga bangsawan biasa mengambil anak-anak dari golongan sudra, seperti Kemuning, untuk mengabdi di Griya. Orang tua mereka pun umumnya ikhlas dan bahagia. Bahkan ada rasa kebanggaan tersendiri, apa lagi kalau sampai puteri mereka disunting bangsawan dan menjadi bagian keluarga Griya. Mereka akan menjadi topik cerita, pusat teladan dan kekaguman, dan mendapat tempat terhormat dikalangan golongannya sendiri. Sebuah kebanggaan yang kadang kejam, ketika harus ditebus dengan pengorbanan seumur hidup" (Rusmini, 2003:78).

Kutipan di atas menunjukkan bahwa latar sosial dalam masyarakat yaitu kaum sudra yang mengabdi untuk kaum bangsawan dengan kerelaan dan pengorbanan seumur hidup.

\section{Implikasi Unsur Intrinsik Novel Kenanga Untuk Pengajaran Sastra}

Salah satu masalah dalam pengajaran sastra yaitu kurangnya kemampuan guru dalam memilih bahan ajar yang aktual dan bermanfaat. Hal ini sering terjadi siswa 


\section{Edutainment : Jurnal Ilmu Pendidikan dan Kependidikan}

Volume 7 Nomor 2 Edisi Juli-Desember 2019

menjadi bosan bila sudah masuk pada ranah pengajaran sastra. Secara umum guru mempunyai tanggung jawab dapat mengubah dan mampu memberikan yang terbaik bagi siswa. Bahan ajar yang disajikan diharapkan dapat menggairahkan dan menyenangkan.

Novel Kenanga salah satu novel yang dapat memberikan gairah dan rasa senang siswa untuk membacanya. Secara umum novel Kenanga mempunyai daya tarik tersendiri bagi pembacanya. Hal ini dapat memberikan semangat kepada siswa untuk meningkatkan salah satu kompetensi kamahiran berbahasa.

Dalam belajar bahasa Indonesia dikenal empat macam kemahiran bahasa, yakni kemahiran mendengar, membaca, berbicara, dan menulis. Kemahiran mendengar dan membaca bersifat reseptif, sedang kemahiran berbicara dan menulis bersifat produktif. Penguasaan bahasa yang ideal mencakup keempat jenis kemahiran tersebut, walaupun kenyataannya masih ada siswa yang malas membaca dan rendah kemampuan menulis. Sehingga dengan novel Kenanga sebagai salah satu bahan ajar pengajaran sastra dapat meningkatkan kemampuan membaca siswa.

Bahan ajar novel Kenanga dapat memberikan solusi bagi guru yang mengalami kesulitan menjangkau novelnovel angkatan 20-an, seperti Belenggu,
Siti Nurbaya, Salah Pilih, Salah Asuhan. Karena novel tersebut sekarang ini di samping susah didapat, juga bahasanya sukar dipahami. Kendala inilah yang mengakibatkan siswa enggan membaca novel tersebut. Sehingga novel Kenanga merupakan salah satu novel yang dapat digunakan dalam pembelajarn sastra.

Kompetensi dasar dapat dikembangkan melalui novel Kenanga sebagai bahan ajar novel Indonesia. Tokoh, penokohan, dan latar yang terdapat dalam novel Kenanga merupakan bagian unsur intrinsik, sehingga tokoh, penokohan, dan latar ini berimplikasi terhadap pengajaran sastra.

Untuk menciptakan komunikasi yang baik antara pembelajar dan pengajar, diperlukan materi pelajaran yang fungsional. Secara fungsional novel Kenanga sebagai salah satu bahan ajar, novel Kenanga memberikan gairah baru terhadp pengajaran sastra di SMA yang cenderung terpaku pada silabus. Guru dituntut lebih aktif dan kreatif dalam mengembangkan bahan ajar yang lebih aktual. Kemampuan guru sangatlah penting, agar minat siswa dalam pengajaran sastra makin meningkat.

Proses pengajaran analisis unsur intrinsik dalam novel Kenanga merupakan bagian belajar membaca dan menghayati isi wacana yang dibacanya. Hal ini berarti, sebelum guru memberikan tugas analisis 
harus diawali dengan informasi-informasi. Karena tingkat pemahaman masingmasing siswa berbeda satu dengan yang lain. Ada siswa yang mudah mencerna informasi, ada pula yang lambat, sehingga guru harus mampu mengondisikan situasi awal.

\section{KESIMPULAN DAN SARAN}

Dari hasil pembahasan dapat disimpulkan pentingnya memahami dan mengetahui unsur intrinsik suatu novel. Dengan mengetahui dan memahami unsur intrinsik suatu novel pembaca dapat memahami isi novel.

Implikasi unsur intrinsik dalam novel Kenanga Karya Oka Rusmini terhadap pengajaran sastra dititikberatkan pada sumber bahan ajar yang mengacu pada tujuan pengajaran sastra. Guru harus mempunyai ciri khas dalam menyampaikan materi pelajaran di depan kelas. Dari ciri tersebut guru mempunyai strategi yang baik dan dapat menggugah gairah siswa untuk mengikuti pelajaran dengan baik.

Sesuai dengan simpulan itu dapat dikemukakan saran bahwa novel Kenanga merupakan penelitian awal unsur intrinsik. Hasil penelitian masih belum lengkap, sehingga hasil penelitian ini dapat menjadi bahan acuan kepada siapapun untuk penelitian lanjut dan untuk dikaji lebih luas. Dari penelitian ini juga dapat digunakan sebagai sumbangan dalam pengembangan di dunia pendidikan terutama di bidang sastra. Dari hasil analisis unsur intrinsik sangatlah berguna untuk pengembangan bahan ajar, khususnya terhadap pengajaran sastra.

\section{DAFTAR PUSTAKA}

Pradopo, Rachmat Djoko. 1997. Pengkajian Puisi. Yogyakarta: Gadjah Mada University Press.

Rusmini, Oka. 2003. Kenanga. Jakarta: Grasindo.

Sayuti, Suminto A. 2000. Berkenalan dengan Prosa Fiksi. Yogyakarta: Gama Media. 